Mer ansvar - mer frigjøring?

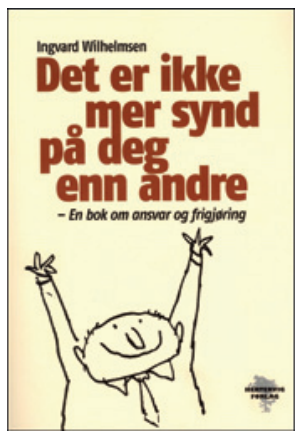

Ingvard Wilhelmsen

Det er ikke mer synd på deg enn andre

En bok om ansvar og frigjøring. 150 s, ill.

Stavanger: Hertervig Akademisk, 2011.

Pris NOK 250

ISBN 978-82-8216-131-2

Indremedisineren og psykiateren Ingvard Wilhelmsen har hatt stor suksess med flere bøker hvor budskapet er: Ta ansvar for ditt liv! Det er ikke dine traumer, men hvordan du tar dem, som avgjør hvilke konsekvenser de får. Dette budskapet gjentas og belyses i denne nye boken.

Det er ikke mer synd på deg enn andre består av to hoveddeler: Den ene delen er en gjennomgang av det kognitive perspektivet på angst, spesielt helseangst, og hvordan forfatteren møter dette i sin praksis. I det vesentlige er dette et sammendrag av hva forfatteren har skrevet interessant og godt om i sine tidligere bøker. Den andre delen er en tekst som består av en pasients («Berit») egen historie over mange år, og forfatterens journalnotater fra to konsultasjoner og senere oppfølgende etterundersøkelse tre år etterpå. Det opplyses at pasienten hadde diagnosene ustabil og narsissistisk personlighetsforstyrrelse, $\mathrm{i}$ tillegg til bipolar lidelse, og hadde erfaring fra mangeårig psykiatrisk og psykoterapeutisk behandling før hun kom med sin helseangst til forfatteren. Dette møtet utløste et vendepunkt $\mathrm{i}$ hennes liv, og det er hennes skildring av prosessen hun så gjennomgår videre på egen hånd, som gjør denne boken interessant.

«Berit» forteller på en svært autentisk måte hvordan en konfronterende (og sårende) bemerkning fra forfatteren (tittelen på boken) klargjorde hvordan hun ubevisst hadde forsterket og klamret seg fast til en offerrolle. Etter denne enkeltstående konfrontasjonen mobiliserte hun sine ressurser og gikk inn i en positiv, selvstyrt utviklingsprosess der hun, godt hjulpet av en nær venninne, tok mer og mer ansvar for seg selv, sine relasjoner og handlinger. Til hennes historie knytter så forfatteren noen enkle kommentarer om empati, selvtillit, skyld, skam og mobbing, og noen korte redegjørelser om hva personlighet, personlighetsforstyrrelse og bipolar lidelse er.

Hennes utviklingsprosess og dens stadier er svært gjenkjennbare for den som har arbeidet psykoterapeutisk med pasienter med alvorlige personlighetsforstyrrelser. Fortellingen illustrerer godt hvordan slike pasienter kan reagere positivt når de blir konfrontert med sine ubevisste relasjonsmønstre. «Konfrontasjon» er en klassisk psykodynamisk intervensjonsmetode: først klargjøring, deretter konfrontering, tolking og til sist gjennomarbeiding.

Forfatteren kommenterer historien utelukkende på et kognitivt nivå. Men uten supplerende begreper som tilknytningsmønster, repetering av internaliserte relasjoner og ubevisste motiver, blir forståelsen av hennes historie for endimensjonal.

Alle med psykoterapeutisk erfaring, enten det er fra terapiformer som kognitiv, psykodynamisk, systemorientert, gestalt, løsningsorientert eller andre, har opplevd at én enkelt intervensjon plutselig har satt en pasient inn på et nytt livsspor. Hvis, og når det skjer, og hos hvilken pasient, er det imidlertid som regel ikke mulig å forutse. Det er etterpå, og iblant først lenge etterpå, at vi kan se et vendepunkt. Det hadde derfor vært ønskelig med mer nøkternhet fra forfatterens side for å unngå at leseren tror at så enkelt er det vanligvis å hjelpe pasienter med langvarig personlighetsproblematikk over i et nytt spor.

\section{Juridisk perspektiv på sykefravær}

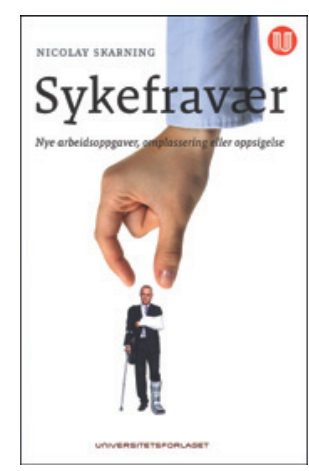

\section{Nicolay Skarning}

Sykefravær

Nye arbeidsoppgaver, omplassering eller oppsigelse. 289 s. Oslo: Universitetsforlaget, 2011. Pris NOK 499

ISBN 978-82-15-01891-1

Forfatteren av denne teksten ser på lovverket som regulerer forholdet mellom arbeidsgiver og den sykmeldte arbeidstakeren. Først og fremst handler det om muligheten for å si opp syke arbeidstakere, eller med motsatt fortegn: oppsigelsesvernet ved sykdom. Men han drøfter også hvor omfattende arbeidsgivers sykefraværsoppfølging må være for å tilfredsstille lovens krav, og hvor langt arbeidsgivers tilretteleggingsplikt går.

Det er nyttig med et juridisk perspektiv på sykefraværet. Juristene vet at partsinteresser ikke alltid lar seg forene. Arbeidslivet er ingen Kardemomme by.

Boken inneholder mye drøfting og ikke mange sikre fasitsvar. Selv om både folketrygdloven og arbeidsmiljøloven angår de fleste, mangler det ofte rettspraksis som kan si oss hvordan lovene skal fortolkes i konkrete saker. Det skyldes vel at syke folk sjelden går til sak, selv om de mener seg ulovlig oppsagt. Dermed blir det heller ikke mange rettsavgjørelser, men desto dårligere rettssikkerhet.

Noen rettssaker blir det likevel, og eksemplene fra rettsvesenet er nyttig lesning. Juristenes talemåter og tankegang er forskjellig fra legenes. Eksemplene kan dempe både legens og pasientens forventninger om at man kan bli «inkludert» $i$ arbeidslivet mot arbeidsgivers ønske. Det er som forfatteren sier i kapitlet om sykefraværsoppfølging: «Sentralt står [...] den ansattes vilje til å komme tilbake $\mathrm{i}$ arbeid, sammen med arbeidsgivers ønske om å kunne benytte vedkommende.» Så enkelt kan det sies. Hvis ett av disse elementene mangler, kan verken møter eller skjemaer bidra til stort mer enn å formalisere oppsigelsen.

Halve boken er opptrykk av sentrale dokumenter som IA-avtalene, standarder for bedriftsavtaler med NAV og sammendrag fra SINTEFs siste evaluering av IA-avtalen. Dette er overflødig stoff for de fleste leger, men idéhistorisk interesserte vil ha glede av å studere utviklingen i begrepsbruk. For eksempel har vi fått et helt nytt ord, «arbeidsinkludering», avledet av originalbegrepet «inkluderende arbeidsliv». Nyordet gjenspeiler at IA-tiltakene stort sett er rettet mot den sykmeldte, sjelden mot forholdene i arbeidslivet. Det er tertiærforebygging fremfor primærforebygging. Det er vel derfor forfatteren bare drøfter arbeidsmiljølovens særbestemmelse om individuell tilrettelegging ( $\$ 4-6)$, og ikke de langt viktigere generelle kravene til et inkluderende arbeidsmiljø. Må ikke rekkevidden av arbeidsgivers tilretteleggingsplikt også vurderes etter om disse paragrafene er etterlevd? Jeg håper det kommer i neste utgave.

Omslaget fremstiller visst sykefraværsoppfølging av den litt ublide typen. Til ettertanke.

\section{Ebba Wergeland}

Arbeidstilsynet

Oslo 